\title{
OSOBITOSTI PRÁVNEJ ÚPRAVY SPOROV S OCHRANOU SLABŠEJ STRANY OPROTI ŠTANDARDNÉMU PRIEBEHU CIVILNÉHO SPOROVÉHO PROCESU
}

\section{PARTICULARITIES OF LAW IN DISPUTES WITH THE PROTECTION OF THE DISADVANTAGED PARTY IN COMPARISON TO THE STANDARD COURSE OF CIVIL DISPUTE PROCESS}

\author{
Miroslava Kušníriková \\ Univerzita Pavla Jozefa Šafárika v Košiciach, Právnická fakulta
}

https://doi.org/10.33542/SIC2019-1-10

\begin{abstract}
ABSTRAKT
Právna úprava sporov s ochranou slabšej strany vychádza a nadväzuje na celkom nové poňatie koncepcie civilného sporového procesu. Rekodifikáciou civilného procesného práva došlo $k$ zakotveniu osobitnej právnej úpravy sporov s ochranou slabšej strany, ktorými sú v zmysle Civilného sporového poriadku spotrebitel, zamestnanec a diskriminovaná osoba. Už označenie „, spory s ochranou slabšej strany“ predznamenáva, že slabšia strana bude mat'v spore určitým spôsobom špecifické postavenie, čomu je prispôsobená aj právna úprava v Civilnom sporovom poriadku, prejavujúca sa $v$ určitých osobitostiach oproti štandardnému priebehu civilného sporového procesu. Primárny ciel', sledovaný právnou úpravou vzt’ahujúcou sa na slabšiu stranu, spočiva $v$ dorovnaní, resp. vyvážení (prirodzene nerovného) postavenia slabšej strany vo vztahu $k$ druhej sporovej strane. Predmetom tohto príspevku je úvaha o tom, či právna úprava sporov $s$ ochranou slabšej strany, tento zámer naplnila.
\end{abstract}

\begin{abstract}
The legal settlement of disputes with the protection of the disadvantaged party is based on a new approach to the civil dispute process concept. Recodification of civil procedural law has resulted in the establishment of a special legal arrangement for disputes with the protection of the disadvantaged party, which, according to the Civil Dispute settlement, is a consumer, an employee and a discriminated person. Already the term "disadvantaged party protection" means that the disadvantaged party will have a specific position in the dispute, which is also adapted to the law in the Civil Dispute settlement, and therefore in certain peculiarities in comparison to the standard course of the civil dispute process. The primary objective pursued by the legislation regarding the disadvantaged party is to balance the (naturally unequal) position of the disadvantaged party in comparison to the other party. The aim of this article is to consider whether the legislation of disputes with the protection of the disadvantaged party has fulfilled this intention.
\end{abstract}




\section{I. ÚVOD}

Osobitná právna úprava sporov podl'a Civilného sporového poriadku, kde jednou z procesných strán je tzv. slabšia strana, sa vyznačuje určitými odchýlkami v porovnaní so štandardným civilným sporovým procesom. Slabšou stranou Civilný sporový poriadok označuje spotrebitel'a, zamestnanca a diskriminovanú osobu. Zákonodarca zvolil za slabšie práve tieto tri skupiny subjektov, pridŕžajúc sa judikatúry Súdneho dvora Európskej únie. Určitým spôsobom zvýhodňujúca právna úprava, týkajúca sa slabšej strany, nie je „nóvum“ na úrovni práva Európskej únie, kde sa tejto problematike už desat'ročia venuje náležitá pozornost', ani v našich podmienkach. Už predchádzajúca právna úprava (zákon č. 99/1963 Zb. Občiansky súdny poriadok) obsahovala ustanovenia, ktoré sa snažili ochránit' záujmy spotrebitel'ov. Právna úprava v Občianskom súdnom poriadku však bola značne nekonzistentná a reagovala čiastkovými zmenami na dynamicky sa rozvíjajúce spotrebitel'ské právo a potrebu jeho procesnej úpravy. Rekodifikácia civilného procesu tak vytvorila priestor pre ucelenú právnu úpravu týkajúcu sa sporov s účast'ou slabšej strany, ktorá je obsiahnutá v druhej hlave tretej časti Civilného sporového poriadku.

To, že spotrebitel', zamestnanec alebo diskriminovaná osoba je slabšou stranou v civilnom sporovom procese, môže byt' dané viacerými dôvodmi. Medzi najčastejšie uvádzané aspekty ${ }^{1}$, patria náklady na samotné konanie a doba jeho trvania, ktoré môžu byt' pre spotrebitel'a, zamestnanca či diskriminovanú osobu odradzujúcimi skutočnost'ami. St'ažená pozícia pre slabšiu stranu môže vychádzat' aj z toho, že takýto spor môže byt' vôbec prvým kontaktom so súdnym systémom, kým u dodávatel'a, zamestnávatel'a a diskriminujúceho sa predpokladá, že vzhl'adom na svoje postavenie už mohli byt' stranami takýchto sporov a každým d'alším sporom získavajú skúsenosti, ktoré dokážu zúročit’ v efektívne realizovanej procesnej obrane. Podstatne závažnejším sa z nášho pohl'adu javí možný informačný deficit v prípade slabšej strany, ktorý je v praxi vel'mi častou realitou. Ide o situáciu, kedy slabšia strana nedisponuje všetkými poznatkami, ktorými by mohla podporit' svoj nárok, pretože nemusí mat' prístup k informáciám a dokumentom, ktorými disponuje protistrana. Na preklenutie týchto potencionálnych negatívnych skutočností na strane slabšieho subjektu slúži osobitná právna úprava týchto typov sporov, ktorú môžeme vnímat’ aj ako tzv. pozitívnu diskrimináciu, prejavujúcu sa právnou úpravou, pri ktorej sa na slabšiu stranu vzt’ahujú určitým spôsobom zmiernené prvky a inštitúty, bežne uplatňované v civilnom sporovom procese. Naznačené odlišnosti sa $\mathrm{v}$ značnej miere týkajú pozmeneného uplatňovania princípov oproti štandardnému civilnému sporovému procesu a to bud' ich oslabením, alebo dokonca úplným vylúčením ich uplatňovania, za účelom eliminácie možných negatívnych procesných následkov, ktoré sa s ich uplatňovaním v ,prísnom“ spore spájajú.

Predmetom príspevku sú vybrané princípy civilného procesu a ich dopad na spory s ochranou slabšej strany, rozšírená poučovacia povinnost' súdu vo vzt'ahu k slabšej strane, či odchýlky v rámci štádia dokazovania, čo je predovšetkým dôsledok výraznej modifikácie prejednacieho princípu. Podrobná analýza vybraných osobitostí sporov s ochranou slabšej strany podl'a Civilného sporového poriadku bude zameraná aj na kritické posúdenie vhodnosti tej-ktorej osobitosti v rámci právnej úpravy, a tým primeranosti odklonu od štandardného civilného sporového procesu za účelom ochrany slabšej strany.

1 ktoré su najviac rozpracované v prípade spotrebitel'ských sporov, ale nepochybne ich môžeme vzt'ahovat' aj na postavenie zamestnanca a diskriminového. 


\section{UPLAŇOVANIE VYBRANÝCH PRINCÍPOV PRI SPOROCH S OCHRANOU SLABŠEJ STRANY}

\section{Explicitné zakotvenie princípu ochrany slabšej strany}

Princípy v civilnom sporovom procese predstavujú vel'mi dôležitý element, nakol'ko aj prostredníctvom ich interpretácie a aplikácie sa dosahujú ciele vytýčené rekodifikáciou. Potreba ochrany slabšej strany je normovaná v článku 6 Civilného sporového poriadku, ktorý primárne zakotvuje princíp rovnosti zbraní, ako klasický princíp, uplatňovaný v kontradiktórnych typoch procesov. Zákonodarca poukazuje na existenciu slabšej strany formou potreby výnimky zo „štandardného“ uplatňovania princípu rovnosti strán deklarovaním skutočnosti, že v niektorých prípadoch je pre dosiahnutie rovnosti potrebné jednu zo sporových strán podporit' „nadštandardne“. Princíp rovnosti zbraní deklaruje, že strany sporu majú v konaní rovné postavenie, ktoré spočíva $\mathrm{v}$ poskytnutí rovnakej miery uplatňovania prostriedkov procesného útoku a procesnej obrany. Obsah princípu rovností zbraní v sebe zahíňa len vytvorenie rovnakej možnosti ohl'adne uplatňovania prostriedkov procesného útoku a procesnej obrany. To, či strana sporu toto procesné oprávnenie, ktoré jej vyplýva z predmetného princípu aj v spore využije, je výlučne na jej uvážení a využitie, resp. skôr nevyužitie procesného oprávnenia stranou už nie je obsahom princípu rovností zbraní. Naznačenou výnimkou je povaha niektorých prejednávaných vecí, vyžadujúca si zvýšenú ochranu jednej strany sporu, s ciel'om vyvažovat' jej prirodzene nerovnovážne postavenie v hmotnoprávnom vzt'ahu a následne aj vo vzt'ahu procesnoprávnom.

Uplatňovanie princípu ochrany slabšej strany je prirodzenou súčast’ou právnej ochrany nielen $\mathrm{v}$ našich podmienkach. Úprava doktríny právneho postavenia slabšej strany je rozpracovaná aj na úrovni práva Európskej únie a prejavuje sa v úlohe súdu vyvažovat' určité nevýhody, ktoré na strane slabšej strany potencionálne môžu existovat'. Pri princípe ochrany slabšej strany je miera jeho uplatňovania zo strany súdu daná pomerne jasne- má byt' uplatňovaný, len kým sa nedosiahne naplnenie princípu rovností zbraní. Podstatou ochrany slabšej strany v procesnoprávnych vzt'ahoch je tak dorovnanie procesného postavenia tejto slabšej strany na tú úroveň, ktorá funkčne koreluje s procesným postavením protistrany (,silnejšej“" procesnej strany) ${ }^{2}$. Tento zámer pramení z poznatku, že v prípade sporov s ochranou slabšej strany, táto, zjednodušene povedané, $v$ spore nezačína na rovnakej úrovni ako protistrana a preto je potrebné prostredníctvom určitých zvýhodnení pre slabšiu stranu, dosiahnut' priblíženie jej procesného postavenia $\mathrm{k}$ procesnému postaveniu protistrany. Touto požiadavkou je daný zvýšený nárok na súdy, aby našli tú „správnu“ mieru aplikácie princípu ochrany slabšej strany, za súčasného zachovania kontradiktórnych prvkov civilného sporového procesu, ktorý si túto, pre neho charakteristickú črtu musí zachovat' aj v prípade týchto osobitných typov sporov. Princíp ochrany slabšej strany si vynucuje zvýšenú mieru ingerencie súdu do konania oproti štandardnému sporu, kde súd vystupuje v pozícii arbitra a v zásade nemôže zasahovat' do spôsobu, akým strany realizujú svoju procesnú obranu prostredníctvom prostriedkov procesného útoku a obrany. Pri sporoch s ochranou slabšej strany je participácia súdu v konaní zvýšená a jednostranne orientovaná práve na slabšiu stranu, za účelom jej ochrany v spore, pričom súd čiastočne formuje realizáciu prostriedkov procesného útoku slabšej strany a to predovšetkým prostredníctvom poučovacej povinnosti a modifikovaného prejednacieho princípu.

2 ŠTEVČEK, M., In: Števček M., Ficová S., Baricová J., Mesiarkinová S., Bajánková J., Tomašovič M. a kol.: Civilný sporový poriadok. Komentár. Praha. C. H. Beck, 2016, str. 45. 


\section{Koncentračný princíp}

Výnimka z uplatňovania princípov v štandardnom sporovom procese je zákonodarcom výslovne upravená v časti upravujúcej spory s ochranou slabšej strany a prejavuje sa pri aplikovaní princípu koncentrácie. Koncentrácia sa $\mathrm{v}$ zmysle Civilného sporového poriadku delí na zákonnú a sudcovskú a prispieva $\mathrm{k}$ dynamickosti civilného sporového procesu tým, že obsahuje hrozbu uplatnenia sankcie, spočívajúcej v nepriznaní procesných účinkov úkonom vykonaných po lehote stanovenej koncentrančným princípom. Princíp koncentrácie týmto spôsobom motivuje strany sporu, aby všetky podstatné a rozhodujúce skutkové tvrdenia a návrhy na vykonanie dôkazov predniesli včas a umožnili tak súdu čo najskôr sformovat' predmet konkrétneho konania. Ak strany nepostupujú $\mathrm{v}$ súlade $\mathrm{s}$ týmito požiadavkami, riskujú uplatnenie negatívnych následkov, ktoré koncentračný princíp so sebou prináša a to, že ich skutkové tvrdenia a návrhy na vykonanie dôkazov, nebudú zo strany súdu zohl'adnené na t’archu tej- ktorej sporovej strany. V prípade sudcovskej koncentrácie je uplatnenie procesných následkov na úvahe súdu, t.j. nemusí nevyhnutne dôjst' $\mathrm{k}$ ich aplikácii, kým následky, ktoré prináša zákonná koncentrácia, sa po splnení predpokladov upravených $\mathrm{v} \S 154$ C.s.p. uplatnia automaticky.

Sudcovská koncentrácia, označovaná aj prívlastkom vhodná, spočíva $\mathrm{v}$ možnosti súdu po náležitej úvahe neprihliadnut' na skutkové tvrdenia a návrhy na vykonanie dôkazov strany v prípade, ak tá nekonala s náležitou starostlivost'ou. Kým v štandardnom civilnom sporovom procese je sudcovská koncentrácia uplatňovaná voči obom stranám sporu, pri sporoch s ochranou slabšej strany je úplne vylúčená vo vzt’ahu k slabšej strane. To znamená, že slabšia strana môže produkovat' nové skutkové tvrdenia a návrhy na vykonanie dôkazov, ktoré majú podporit' a preukázat' jej tvrdenia v celom priebehu konania, až do momentu vyhlásenia rozhodnutia vo veci samej. Výnimku z vylúčenia aplikácie sudcovskej koncentrácie v spore s ochranou slabšej strany predstavuje situácia, ak je spotrebitel' podl’a ustanovenia § 291 ods. 3 C.s.p. zastúpený advokátom. $\mathrm{V}$ takomto prípade sa koncentračný princíp aplikuje tak, ako to upravuje $\S 153$ ods. 1 a ods. 2 C.s.p. Uvedené vychádza z toho, že ak spotrebitel' disponuje kvalifikovanou právnou pomocou, ktorou zastúpenie advokátom nepochybne je, tak nie je dôvod postupovat' $\mathrm{v}$ zmiernenej podobe koncentračného princípu, nakol'ko k dorovnaniu procesného postavenia slabšej strany vo vzt’ahu k protistrane došlo práve zastúpením advokátom.

Zákonná koncentrácia, ktorá je $\mathrm{v}$ klasickom sporovom procese ohraničená vydaním uznesenia o skončení dokazovania a vzt’ahuje sa na obe strany, je pri sporoch s ochranou slabšej strany opätovne jednostranne posunutá len vo vzt’ahu k slabšej strane, a to až do momentu vyhlásenia rozhodnutia vo veci samej. Vylúčením sudcovskej koncentrácie a posunutím zákonnej, ktoré môžeme súhrne považovat' za oslabenie koncentračného princípu, sa slabšej strane priamo zo zákona vytvárajú priaznivejšie podmienky pre uplatňovanie prostriedkov procesného útoku, ktoré sa javia ako zvýhodňovanie slabšej strany oproti protistrane. Tento stav je vyvažovaný tým, že protistrane sa musí poskytnút' možnost' na uplatnený procesný útok slabšej strany procesne reagovat'. S týmto záverom sa stotožnila aj prof. Ficová: „obmedzenie vyplývajúce zo zákonnej alebo sudcovskej koncentrácie konania môže platit’ pre silnejšiu stranu len pre použitie prostriedkov procesného útoku, nie pre použitie prostriedkov procesnej obrany"3. Ak by tomu tak nebolo, tak v sporoch s ochranou slabšej strany by reálne mohlo dôjst' $\mathrm{k}$ situácii, že slabšia strana by určité rozhodujúce skutočnosti zámerne predostrela až po lehote, $v$ rámci ktorej môže protistrana uplatňovat' prostriedky procesného útoku a obrany, pretože ju zat'ažuje koncentračný princíp vo svojom štandardnom vymedzení v zmysle Civilného sporového poriadku a tým by jej fakticky

3 FICOVÁ S., Kam až siaha princíp ochrany slabšej strany? In: Košické dni súkormného práva I., 2016, str. 598. 
znemožnila uplatnit' prostriedky procesnej obrany. Uvedené vychádza z vyššie spomenutého princípu rovnosti strán, kedy stranám musí byt' vytvorená objektívna možnost' uplatňovat' prostriedky procesného útoku a obrany v rovnakej miere. V nadväznosti na vylúčenie princípu koncentrácie u slabšej strany sa obsah princípu rovnosti strán prejavuje práve v poskytnutí možnosti protistrane reagovat' na uplatnené prostriedky procesného útoku slabšej strany. S určitost'ou môžeme tvrdit', že základným zmyslom oslabenia princípu koncentrácie vo vzt'ahu k slabšej strane, je predovšetkým odstránenie negatívnych následkov podla Civilného sporového poriadku spájaných s jeho nedodržaním, ktoré spočívajú v možnosti neprihliadnut' na skutkové tvrdenia alebo návrhy na vykonanie dôkazov a v následnom nepriznaní procesných účinkov.

Obdobne ako pri zákonnej, tak aj pri sudcovskej koncentrácii platí, že ak je spotrebitel' zastúpený advokátom, ustanovenie § 296 C.s.p. sa nepoužije. Zákonná koncentrácia v zmysle štandardného priebehu civilného sporového procesu sa uplatňuje aj pri konaní o abstraktnej kontrole v spotrebitel'ských veciach, kde sa podl'a ustanovenia § 303 ods. 3 C.s.p. nepoužijú len ustanovenia o sudcovskej koncentrácii konania.

Vzhl'adom na vyššie poukázaný prístup, vo vzt'ahu k právnej úprave sporov s ochranou slabšej strany ohl'adne oslabenia princípu koncentrácie, sa do popredia dostáva otázka, prečo zákonodarca len pri jednej kategórii slabšej strany- a to spotrebitel'ovi pristúpil k úprave, ktorá v prípade zastúpenia advokátom vylučuje použitie ustanovenia $§ 296$ C.s.p. ${ }^{4}$ Tento postup upravený v prípade spotrebitel'ských sporov, je úplne na mieste, nakol'ko obmedzenie pôsobenia koncentračného princípu napomáha slabšej strane, ktorá nemá kvalifikovanú právnu pomoc prostredníctvom advokáta, aby sa na ňu nevzt’ahovali sankčné následky, ktoré koncentrácia so sebou v klasickom civilnom spore prináša. Preto z nášho pohl'adu by totožný postup pri právnej úprave opätovného uplatňovania princípu koncentrácie mal byt' aplikovaný aj v prípade zastúpenia zamestnanca a diskriminovanej osoby $\mathrm{v}$ spore advokátom. Ak zamestnanec a diskriminovaný je zastúpený v spore s ochranou slabšej strany advokátom, „stiera“ sa touto kvalifikovanou právnou pomocou jeho procesné znevýhodnenie oproti protistrane. Civilný sporový poriadok však v antidiskriminačných sporoch a individuálnych pracovnoprávnych sporoch pri zastúpení advokátom nepristúpil k vylúčeniu ustanovení $\S 312$ a $\S 320$ C.s.p. upravujúcich vylúčenie koncentrácie, čím zamestnanec a diskriminovaný svoje procesné postavenie slabšej strany v spore dokážu odstránit' jednak prostredníctvom advokáta a zároveň im je stále ponechaná možnost' uplatňovat' prostriedky procesného útoku spočívajúce v predložení a označení všetkých skutočností a dôkazov, na preukázanie ich tvrdení až do vyhlásenia rozhodnutia vo veci samej, čím z nášho pohl'adu nastáva vybočenie z medzí princípu ochrany slabšej strany, ktoré sú dané princípom rovností strán a de facto tak dochádza $\mathrm{k}$ favorizácii slabšej strany, ktorou je zamestnanec a diskriminovaný zastúpený advokátom oproti protistrane.

\section{ZABEZPEČENIE OSOBITNÉHO PROCESNÉHO POSTAVENIA SLABŠEJ STRANY}

\section{Inštitúty spojenia vecí na spoločné konanie a zmena žaloby}

Pri spotrebitel'ských typoch sporov sa ustanovenie $\S 166$ C.s.p., ktoré upravuje spojenie takých konaní na spoločné konanie, ktoré začali pred tým istým súdom a bud' spolu súvisia skutkovo alebo sa týkajú tých istých strán, môže aplikovat' len $\mathrm{v}$ prípade, ak by predmetom konaní boli spotrebitel'ské spory. Pri $§ 293$ ods. 1 C.s.p., ide o vyriešenie otázky aplikácie dvoch princípov, a to princípu ochrany slabšej strany a zároveň princípu hospodárnosti konania, kde štandardne (v

4 ktoré umožňuje spotrebitel'ovi predložit' alebo označit' všetky skutočnosti a dôkazy na preukázanie svojich tvrdení najneskôr do vyhlásenia rozhodnutia vo veci samej, ustanovenia o sudcovskej a zákonnej koncentrácii konania sa nepoužijú. 
klasickom sporovom procese) by došlo práve po zohladnení princípu hospodárnosti konania $\mathrm{k}$ spojeniu vecí na spoločné konanie. Avšak prítomnost' princípu ochrany slabšej strany odôvodňuje odklon od tohto postupu. Uvedeným sa sleduje predovšetkým možnost', že medzi dodávatel'om a spotrebitel'om môže prebiehat' aj iný ako spotrebitel'ský typ sporu a v takom prípade, ak by došlo k spojeniu spotrebitel'ského sporu a iného ako spotrebitel'ského typu sporu, pre súd by bolo nepochybne náročné rozlišovanie osobitného procesného postavenia spotrebitel'a a tomu zodpovedajúce aplikovanie osobitostí na vyváženie jeho postavenia oproti protistrane v inom, ako spotrebitel'skom spore. Nakol'ko princípy majú rovnocenné postavenie a žiaden z nich nie je automaticky nadradený inému, zákonodarca túto kolíziu vyriešil práve ustanovením § 293 ods. 1 C.s.p., čím dal prednost' uplatneniu princípu ochrany slabšej strany - a to prostredníctvom zákazu spojenia iných ako spotrebitel'ských vecí, na úkor princípu hospodárnosti konania.

Koncepcia nezmiešavania sporov s ochranou slabšej strany s inými spormi (hoci vedenými medzi tými istými sporovými stranami) sa uplatňuje aj v prípade objektívnej kumulácie, spôsobenej vzájomnou žalobou - ak vzájomná žaloba nepredstavuje spor s ochranou slabšej strany (t.j. pôjde o iný právny vztah), súd vzájomnú žalobu vylúči na samostatné konanie (§ 293 ods. 2 a $\S 310$ C.s.p.). Účelom zvoleného postupu je vylúčenie toho, aby procesný útok dodávatel'a (alebo diskriminujúcej osoby), spočívajúci vo vzájomnej žalobe obral spotrebitel'a (alebo diskriminovanú osobu) o procesné postavenie slabšej strany. Považujeme za vhodné podotknút', že takéto pravidlo absentuje pri individuálnych pracovnoprávnych sporoch. Dôvodom môže byt' skutočnost', že v tomto spore sa uplatňuje kauzálna príslušnost' súdu (§ 23 C.s.p.), ktorú súd skúma ex officio ( 40 C.s.p.) a v prípade „nehodiacej sa“ vzájomnej žaloby súd túto vylúči na samostatné konanie podl'a všeobecnej procesnej úpravy.

Osobitná úprava vo vzt’ahu k slabšej strane (avšak len k spotrebitel'ovi) sa vzt’ahuje aj na inštitút zmeny žaloby. V zmysle § 294 C.s.p. ak spotrebitel' vystupuje na strane žalovaného, tak zmena žaloby je neprípustná. Za zmenu žaloby sa podl’a ustanovenia $\S 140$ ods 1 a ods. 2 C.s.p. považuje návrh, ktorým sa bud' rozširuje uplatnené právo alebo sa uplatňuje iné právo a tiež zmenou žaloby je podstatná zmena alebo doplnenie rozhodujúcich skutočností, ktoré žalobca tvrdil v žalobe. Rovnako ako v štandardnom sporovom procese, ak určitý spôsob usporiadania vzt’ahu medzi stranami vyplýva z osobitného predpisu, tak za zmenu žaloby sa následne nepovažuje úkon žalobcu, ktorým mení uplatnený nárok. Týmto sa pre spotrebitel’a vytvára pomerne výrazná právna istota ohl'adom predmetu sporu.

\section{Rozš́ŕrená poučovacia povinnost' vo vzt'ahu k slabšej strane}

V̌̌eobecne môžeme rozšŕrenú poučovaciu povinnost' súdu vo vzt’ahu k slabšej strane odôvodnene považovat' za vhodný nástroj, ktorým dochádza $\mathrm{k}$ zefektívneniu ochrany práv spotrebitel'a, zamestnanca a diskriminovaného $\mathrm{v}$ antidiskriminačnom spore. Rozšírenú poučovaciu povinnost' má súd povinnost' aplikovat' vo vzt'ahu $\mathrm{k}$ slabšej strane, s výnimkou, ak je slabšia strana zastúpená advokátom alebo ide o obmedzenie poučovacej povinnosti $\mathrm{v}$ rámci štandardného priebehu civilného procesu podl'a ustanovenia $\S 160$ C.s.p. Rozšírená poučovacia povinnost' je upravená v ustanoveniach $\S 292, \S 309, \S 318$ C.s.p., kedy je súd povinný pri prvom procesnom úkone vo vzt'ahu $\mathrm{k}$ spotrebitel'ovi, zamestnancovi a žalobcovi $\mathrm{v}$ antidiskriminačnom spore poučovat' o možnosti zastúpenia, o procesných právach a povinnostiach a to nie len $\mathrm{v}$ rozsahu všeobecnej poučovacej povinnosti ${ }^{5}$, o dôkazoch, ktoré je potrebné predložit', o možnosti podat'

5 tá je upravená v ustanovení § 160 C.s.p. 
návrh na vydanie neodkladného alebo zabezpečovacieho opatrenia a aj o iných možnostiach potrebných na účelné uplatňovanie alebo bránenie ich práv.

Mantinely v prípade rozšírenej poučovacej povinnosti predstavuje, resp. určuje hmotné právo spolu s princípom rovnosti strán v konaní. Súd nesmie poučovat' ani slabšiu stranu o hmotnom práve, pretože by sa vystavil riziku porušenia rovnosti strán ${ }^{6}$. Rozšírená poučovacia povinnost' sa má týkat' procesného postavenia slabšej strany a má smerovat' k tomu, aby slabšia strana mohla svoje právo na súdnu ochranu uplatnit' efektívne. Mohli by sme povedat', že poučenie slabšej strany má viest' k „zvýšeniu jej procesného povedomia v spore,“ a má smerovat' ku skvalitatívneniu prostriedkov procesného útoku a procesnej obrany slabšej strany tak, aby podané návrhy smerovali k podstate veci. $\mathrm{V}$ praxi je ale niekedy vel'mi náročné určit' presnú hranicu, ktorá existuje medzi právom hmotným a na neho nadviazaným procesným právom. Poučovacia povinnost' umožňuje pružne reagovat' jednak na priebeh konkrétneho sporu s ochranou slabšej strany a tiež individuálne zohl'adnit' slabšiu stranu v konkrétnom konaní, čím môže byt' zo strany súdu ,ušitá na mieru“ konkrétnej slabšej strane. $Z$ nášho pohl'adu je práve rozšírená poučovacia povinnost' najdôležitejším prvkom z celej škály špecifík aplikovaných za účelom ochrany slabšej strany, pretože súd prostredníctvom nej môže prispiet' $\mathrm{k}$ tomu, aby slabšia strana dokázala $\mathrm{v}$ spore uplatnený nárok podporit' z hl'adiska civilného procesného práva efektívnym spôsobom.

Úloha a následná zodpovednost' súdu v rámci rozšírenej poučovacej povinnosti nie je vôbec triviálna. Pochybenie súdu v prípade porušenia poučenia slabšej strany je potrebné skúmat' $\mathrm{z}$ hl'adiska intenzity a jeho vplyvu na práva slabšej strany, nakol'ko nie každé pochybenie súdu pri poučení slabšej strany musí automaticky vyústit', resp. nemusí byt' naplnený dôvod na podanie odvolania. Ak by porušenie poučenia zo strany súdu bolo v takej miere, že tým došlo k porušeniu práva spotrebitel'a, zamestnanca a diskriminovaného na spravodlivý proces, slabšia strana je oprávnená podat' opravný prostriedok, ktorým je odvolanie, nakol'ko bude naplnený odvolací dôvod v zmysle $§ 365$ ods. 1. písm. c C.s.p. ${ }^{7}$.

\section{Jednostranné vylúčenie možnosti vydania kontumačného typu rozsudku}

Teória procesného práva pozná viaceré druhy súdnych rozhodnutí a ich následné delenie z hl'adiska rôznych kritérií. Rozsudok je súdnym rozhodnutím, ktorým sa vždy rozhoduje vo veci samej ${ }^{8}$. Zaiste, ideálnou situáciou je rozhodnút' o celej prejednávanej veci vydaním rozsudku, ktorý bude možné označit' ako spravodlivý. Rekodifikáciou sporového procesu sa podstatne zvýšili požiadavky na strany sporu ohl'adne ich aktívnej participácie a dalo by sa povedat', že strany sú takmer výlučne zodpovedné za svoj úspech či prípadný neúspech v spore rezultujúci v súdnom rozhodnutí. V rámci vynútenia si procesnej aktivity, je osobitným typom rozsudkov, rozsudok pre zmeškanie, známy aj ako kontumačný rozsudok. Kontumačný rozsudok získal prívlastok sankčného typu rozsudku, nakol'ko sa ním $\mathrm{v}$ sporových konaniach umožňuje procesne sankcionovat' procesná pasivita sporovej strany. V štandardnom civilnom spore, môže byt' kontumačný rozsudok, za splnenia podmienok upravených Civilným sporovým poriadkom, vydaný v neprospech ktorejkol'vek sporovej strany. Práve výlučne sankčný charakter bol zrejme tým dôvodom, na základe ktorého sa pristúpilo $\mathrm{k}$ vylúčeniu vydania tohto typu rozsudku pri sporoch s ochranou slabšej strany, ale len jednostranne a to v neprospech slabšej strany.

\footnotetext{
napríklad o pasívnej vecnej legitimácii alebo čo by malo byt' ciel’om v konaní pre slabšiu stranu. išlo by o odvolací dôvod spočívajúci v porušení práva na spravodlivý proces.

MAZÁK, J., MOLNÁR, P., JANOŠÍKOVÁ, M.: Učebnica občianskeho procesného práva, 2012, str. 359.
} 
Podl'a Civilného sporového poriadku, pri sporoch s ochranou slabšej strany je možné vydat' kontumačný rozsudok len $\mathrm{v}$ neprospech protistrany, nikdy nie $\mathrm{v}$ neprospech slabšej strany. Na uvedenom nič nemení ani to, či slabšia strana vystupuje na pozícii žalobcu alebo žalovaného. Ako bolo vyššie uvedené, podstata rozsudku pre zmeškanie spočíva predovšetkým v procesnej sankcii za procesnú pasivitu v spore. Aj ked' slabšia strana si nepochybne vyžaduje ochranu za účelom vyvažovania resp. dorovnávania jej procesného postavenia v spore, diskutabilným môže byt', či absolútne vylúčenie rozsudku pre zmeškanie je v medziach zámeru deklarovaného zákonodarcom, nakol'ko ani slabšia strana by nemala byt' zbavená povinnosti svojím aktívnym prístupom prispiet' k tomu, aby vec mohla byt' čo najrýchlejšie rozhodnutá. Ochrana slabšej strany zakotvením odlišností v tomto type sporov, by mala byt' uplatňovaná výlučne za účelom vyváženia jej nevýhodnejšieho postavenia a k jej aplikácii by malo dôjst' v situáciách, kedy si slabšia strana určitú procesnú povinnost' $\mathrm{v}$ zmysle požiadaviek kladených na sporové strany $\mathrm{v}$ rámci klasického sporového konania, nevie splnit' práve pre už tol'kokrát spomenuté nerovnovážne postavenie spočívajúce $\mathrm{v}$ objektívnej nemožnosti. Či je správne automatické obmedzenie predovšetkým sankčných následkov voči slabšej strane aj v prípade, ak by malo byt' následkom jej procesnej pasivity, zostáva otvorenou otázkou.

\section{4. Štádium dokazovania a modifikovaný prejednací princíp}

Procesné dokazovanie je výlučne zákonom upravený postup súdu9 ${ }^{9}$ Štádium dokazovania je jedno z najnáročnejších častí civilného sporového procesu a najdôležitejší spôsob budovania skutkového základu meritórneho rozhodnutia súdu ${ }^{10}$. Kvalita jeho výsledku je priamo úmerná procesnej aktivite sporových strán. V rámci dokazovania v klasickom civilnom sporovom procese je v popredí najviac vystupujúcim prejednací princíp. Zo štandardného poňatia prejednacieho princípu sa vyvodzuje pravidlo, v zmysle ktorého súd môže vykonat' len taký dôkaz, ktorý bol navrhnutý niektorou sporovou stranou. $\mathrm{Aj} \mathrm{v}$ rámci klasického priebehu civilného sporového procesu sú zákonom stanovené výnimky, kedy sa toto pravidlo vyplývajúce z prejednacieho princípu prelamuje ${ }^{11}$. Uvedená modifikácia prejednacieho princípu v rámci štandardného priebehu konania je odôvodnená tým, že len v zákonom predvídaných prípadoch, ktoré sú upravené vo forme zákonných výnimiek, súd môže pristúpit’ k vykonaniu nenavrhnutého dôkazu.

Pri sporoch s ochranou slabšej strany je uplatňovaný prejednací princíp oslabený ešte vo väčšej miere. Dalo by sa dokonca povedat', že prestáva platit' jeho základné pravidlo a to, že súd je limitovaný predchádzajúcim návrhom niektorej strany. Práve spomínané značné oslabenie býva často prirovnávané $\mathrm{k}$ tomu, že pri úprave dokazovania so slabšou stranou s poukázaním na odlišností oproti dokazovaniu štandardného priebehu procesu, sa uvádza uplatňovanie vyšetrovacieho princípu. Na tomto mieste považujeme za potrebné zdôraznit', že vyšetrovací princíp ako taký znamená povinnost' súdu vykonat' všetky dôkazy potrebné pre rozhodnutie vo veci. Ak je súd viazaný vyšetrovacím princípom, ktorý je previazaný s princípom materiálnej pravdy, nie je vôbec ovplyvňovaný dôkaznou aktivitou účastníkov konania, a vyšetruje skutočný stav veci aj v prípade absolútnej procesnej pasivity účastníkov v konaní. Nakol’ko v civilnom sporovom procese sa vyšetrovací princíp spolu $\mathrm{s}$ materiálnou pravdou neuplatňuje, tak $\mathrm{v}$ ustanoveniach $\S 295, \S 303$ ods. 2, § 311a § 319 C.s.p., ktoré upravujú možnost' vykonania aj nenavrhnutých dôkazov, je potrebné vychádzat' z toho, že stále ide o aplikáciu prejednacieho

9 MAZÁK, J., MOLNÁR, P., JANOŠÍKOVÁ, M.: Učebnica občianskeho procesného práva, 2012, str. 324.

10 MOLNÁR, P., In: Števček M., Ficová S., Baricová J., Mesiarkinová S., Bajánková J., Tomašovič M. a kol.: Civilný sporový poriadok. Komentár. Praha. C. H. Beck, 2016, str. 797.

11 výnimky podl'a ustanovenia $\S 185$ ods. 2 a ods. 3 C.s.p. 
princípu, aj ked' v značne modifikovanej podobe ${ }^{12}$. Súd by mal vyvíjat' zvýšenú aktivitu súvisiacu s obstaraním dôkazných prostriedkov až v prípade, ked' je to nevyhnutné pre rozhodnutie vo veci samej.

Zmyslom a účelom odklonu od štandardnej podoby prejednacieho princípu v klasickom sporovom procese, je určitým spôsobom napomôct' postaveniu slabšej strany v konaní práve tým, že súd môže vykonat' aj taký dôkaz, ktorý slabšia strana nenavrhla. Nepochybne, zvolená modifikácia prejednacie princípu smeruje aj k vylúčeniu procesných sankcií naviazaných na jeho uplatňovanie, ktorými by bola $\mathrm{v}$ podstate nemožnost' vykonania nenavrhnutých dôkazov iniciatívne zo strany súdu. Priklonenie sa k tak značnej modifikácii prejednacieho princípu má svoje korene v sociálnej funkcii súdneho konania, ktorá je pri sporoch so slabšou stranou citel'ne $\mathrm{v}$ popredí záujmu. Značnú modifikáciu prejednacieho princípu pri sporoch s ochranou slabšej strany je možné vnímat' aj ako ,,poistku“ pre prípad, že k predneseniu návrhu na vykonanie dôkazu od slabšej strany nedôjde ani pri realizácii rozšírenej poučovacej povinnosti súdu. V rámci poučenia slabšej strany, súd okrem iného poučuje aj o dôkazoch, ktoré je potrebné predložit'. Pri sporoch s ochranou slabšej strany je dôležité mat' vždy na pamäti účel sledovaný tak značnou modifikáciou prejednacieho princípu a ani pri tomto type sporov by tak zákonom prípustná modifikácia predmetného princípu nemala byt' uplatňovaná automaticky. Jej aplikácia by mala byt' využitá $\mathrm{v}$ situácii, ak v rámci priebehu konania vyvstane potreba vykonania určitého dôkazu, o ktorom pri poučení slabšej strany súd ešte neuvažoval (v tom čase jeho vykonanie nepovažoval za potrebné) $\mathrm{a}$ ani slabšia strana $\mathrm{v}$ rámci uplatňovania prostriedkov procesného útoku vykonanie dôkazu nenavrhla. Ak slabšia strana bola v rámci širšie koncipovanej poučovacej povinnosti o potrebe predloženia takéhoto dôkazu súdom poučená, a priamo povedané, toto nasmerovanie zo strany súdu odignorovala, súd by podla nášho názoru nemal automaticky postupovat' iniciatívne a vykonat' takýto dôkaz, nakol'ko sa môže dostat' do kolízie s princípom rovnosti zbraní, ked'že princíp ochrany slabšej strany sa uplatňuje len v medziach princípu rovného postavenia sporových strán. Práve pri takto koncipovanej úprave, kedy miera modifikácie princípu nie je striktne daná zákonom, je t’ažisko ohl'adne nájdenia ,tej správnej miery“ oslabenia princípu na súde. V prípade prejednacieho princípu je súd v tomto type sporov limitovaný pomyslenými dvoma bodmi. Jednak je tu požiadavka chránit' slabšiu stranu v zmysle princípu ochrany slabšej strany, ale zároveň je súd povinný rešpektovat' princíp rovnosti zbraní, charakteristický pre kontradiktórny typ procesov, majúc neustále na pamäti skutočnost', že aj ochrana slabšej strany nachádza svoje uplatnenie len $\mathrm{v}$ medziach fair trial.

$\mathrm{V}$ prípade individuálnych pracovnoprávnych sporov je $\mathrm{V}$ rámci úpravy modifikácie prejednacieho princípu výslovne zvýraznená možná dôkazná núdza na strane zamestnanca a to prostredníctvom ustanovenia $§ 319$ C.s.p., druhá veta. Na prekonanie tejto negatívnej situácie, ktorá potencionálne môže nastat', zákonodarca reaguje tak, že sa zakotvuje povinnost' pre zamestnávatel'a poskytnút' súčinnost' pri obstaraní a zabezpečení dôkazov, za podmienky, že to možno od neho spravodlivo požadovat'. Uvedené môže značným spôsobom prispiet' k rozsahu zisteného skutkového stavu súdneho rozhodnutia.

\section{ZÁVER}

V rámci skúmanej problematiky bolo v príspevku poukázané na špecifiká, ktorými sa vyznačujú spory s ochranou slabšej strany. Pre právnu úpravu týchto sporov, kde jednou sporovou stranou je tzv. slabšia strana, je príznačná jednostranne orientovaná aktívnejšia ingerencia súdu do

12 uvedenému nahráva aj gramatický výklad predmetných ustanovení. 
prebiehajúceho konania $\mathrm{v}$ porovnaní so štandardným civilným sporovým procesom, za účelom dosiahnutia vytýčeného ciel'a tejto osobitnej právnej úpravy, spočívajúceho $\mathrm{v}$ dorovnaní procesného postavenia slabšej strany. Nezastupitel'ná úloha súdu spočíva predovšetkým $\mathrm{v}$ rozšírenej poučovacej povinnosti, prostredníctvom ktorej súd usmerňuje slabšiu stranu, aby prostriedky procesného útoku boli z jej strany realizované efektívnym spôsobom.

Pri antidiskriminačných sporoch a individuálnych pracovnoprávnych sporoch vidíme priestor na zváženie vhodnosti nastavenia aktuálnej právnej úpravy v otázke ponechania uplatňovania vylúčenia princípu koncentrácie aj v prípade zastúpenia slabšej strany advokátom, čím podl’a nášho názoru dochádza $\mathrm{k}$ favorizácii zamestnanca a diskriminovaného, nakol'ko ich pôvodné procesné postavenie majúce prívlastok slabšie, bolo odstránené práve zabezpečím si kvalifikovanej právnej pomoci prostredníctvom zastúpenia advokátom. Ako správnym sa javí postup, ktorý je upravený $\mathrm{v}$ prípade spotrebitel'ských sporov, a to, že ak sa spotrebitel' dá v spore zastúpit' advokátom, nebude sa aplikovat' vylúčenie ustanovení o sudcovskej a zákonnej koncentrácii konania.

Značná modifikácia prejednacieho princípu v rámci sporov s ochranou slabšej strany umožňuje pružne reagovat' $v$ prebiehajúcom spore predovšetkým na situáciu, ked' slabšia strana nie je spôsobilá uplatňovat' tak prostriedky procesného útoku, resp. procesnej obrany spôsobom, aký vyžaduje Civilný sporový poriadok $\mathrm{v}$ prípade klasických sporových strán súperiacich $\mathrm{V}$ kontradiktórnom civilnom sporovom procese. Vtedy je úplne namieste zo strany súdu vstúpit' do prebiehajúceho konania a napomôct' odstránit' nežiaduci stav. Avšak aj spory s ochranou slabšej strany by si mali zachovat' kontradiktórne prvky a slabšiu stranu by mal súd aktívne chránit’ len do momentu, kedy ona sama $v$ rámci aktívnej procesnej diligencie prispieva k účinnej ochrane svojich práv. V nadväznosti na to by ochrana slabšej strany zo strany súdu mala byt' len podporná, nadviazaná na procesnú aktivitu tejto strany v spore. Z nášho pohl'adu by zvýšená procesná ochrana spotrebitel'a, zamestnanca a diskriminovaného prostredníctvom osobitnej úpravy v Civilnom sporovom poriadku mala nastúpit' len $\mathrm{v}$ prípadoch objektívnej nemožnosti uplatňovania prostriedkov procesného útoku, resp. procesnej obrany slabšej strany, ktorá môže byt' daná najmä informačným deficitom alebo dôkaznou núdzou a tento zmiernený postup by nemal byt' aplikovaný v prípade jej procesnej pasivity, trvajúcej napriek náležitému poučeniu.

Právna úprava pre spory s ochranou slabšej strany by mala vytvorit’ fungujúci systém, ktorý umožní účinné bránenie práv slabších subjektov, odstráni predovšetkým formálne prekážky, ktoré by spotrebitel'a, zamestnanca a diskriminovaného potencionálne mohli odradit' od podania žaloby na súde, ale zároveň by mali aj v týchto typoch sporov zostat' zachované kontradiktórne prvky charakteristické pre štandardný civilný sporový proces vynucujúce si aj v prípade slabšej strany aktívny prístup pri uplatňovaní prostriedkov procesného útoku za účelom dosiahnutia úspechu $\mathrm{v}$ spore.

\section{KLÚČOVÉ SLOVÁ}

slabšia strana, špecifiká sporov s ochranou slabšej strany, Civilný sporový poriadok.

\section{KEY WORDS}

disadvantaged party, specifics of disputes with protection of disadvantaged party, Civil Dispute settlement. 


\section{POUŽITÁ LITERATÚRA}

1. ŠTEVČEK M., a kol. Prednášky a texty z (nového) civilného procesu. Skriptá 1 vydanie. Bratislava: C.H. Beck 2017. ISBN:978-80-8960-351-0.

2. ŠTEVČEK M., a kol. Civilný sporový poriadok. Komentár. Praha: C.H. Beck, 2016 . ISBN: 978-80-7400-629-6.

3. VOJČÍK P., FILIČKO V., KOROMHÁZ P.(eds.), Košické dni súkromného práva I. Recenzovaný zborník vedeckých prác. Univerzita Pavla Jozefa Šafárika v Košiciach, 2016. ISBN: 978-80-8152-400-4.

4. HORVÁTH E., ANDRÁŠIOVÁ A., Civilný sporový poriadok. Komentár.Bratislava: Wolters Kluwer, 2015. ISBN:978-80-8168-362-6.

5. MAZÁK J., MOLNÁR P., JÁNOŠÍKOVÁ M. Učebnica občianskeho procesného práva. Bratislava: IURIS LIBRI, 2012. ISBN:978-80-8963-500-9.

\section{KONTAKTNÉ ÚDAJE AUTORA}

Mgr. Miroslava Kušníriková

interná doktorandka

Univerzita Pavla Jozefa Šafárika v Košiciach

Právnická fakulta

Katedra občianskeho práva

Kováčska 26, 04075 Košice

Telefón: 0907462992

E-mail: miroslava.kusnirikova@student.upjs.sk 